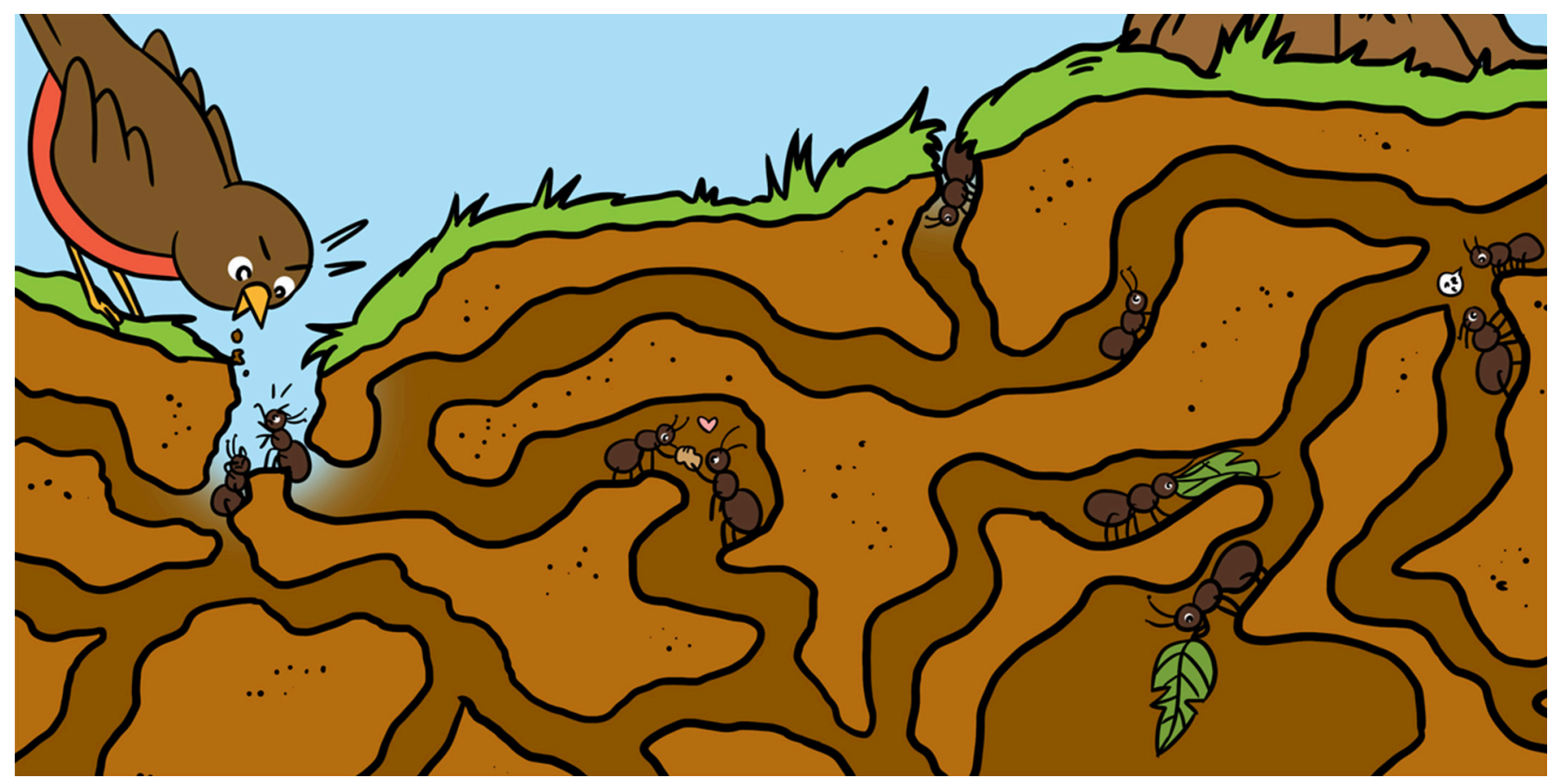

\title{
SPECIES INTERACTIONS AND ANTS
}

\section{Melissa R. L. Whitaker ${ }^{1,2^{*}}$ and Bonnie J. Stolzmann ${ }^{3}$}

${ }^{1}$ Museum of Comparative Zoology, Department of Organismic and Evolutionary Biology, Harvard University, Cambridge, MA, United States

${ }^{2}$ Biocommunication \& Ecology Group, ETH Zürich, Zürich, Switzerland

${ }^{3}$ Spark Gallery, Denver, CO, United States

YOUNG REVIEWERS:

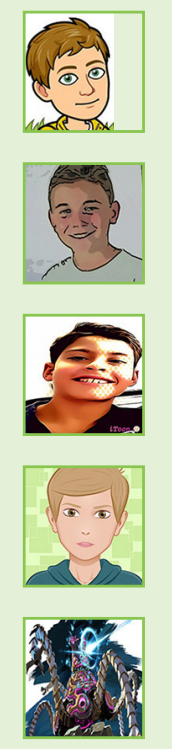
NICOLÁS AGE: 11
All living creatures exist within ecological communities, and they have important interactions with other creatures throughout their lifetimes. Ants are some of the most interactive creatures on Earth-they live in highly social societies and engage in diverse interactions with animals, plants, bacteria, and fungi. This article will introduce you to the major types of interactions that occur between species in nature, called parasitism, competition, and mutualism, and will provide real-life examples from the fascinating world of ants.

\section{INTRODUCTION}

Think of all the interactions you have with living things over the course of the day. You communicate with other humans such as your friends, family, neighbors, and schoolmates. Maybe you play with pets or other animals, and you certainly eat food that came from plants and maybe animals. Just like you do, all living things interact with the other 
Figure 1

A single ant cannot survive on her own; she must interact with her nestmates and many other organisms.

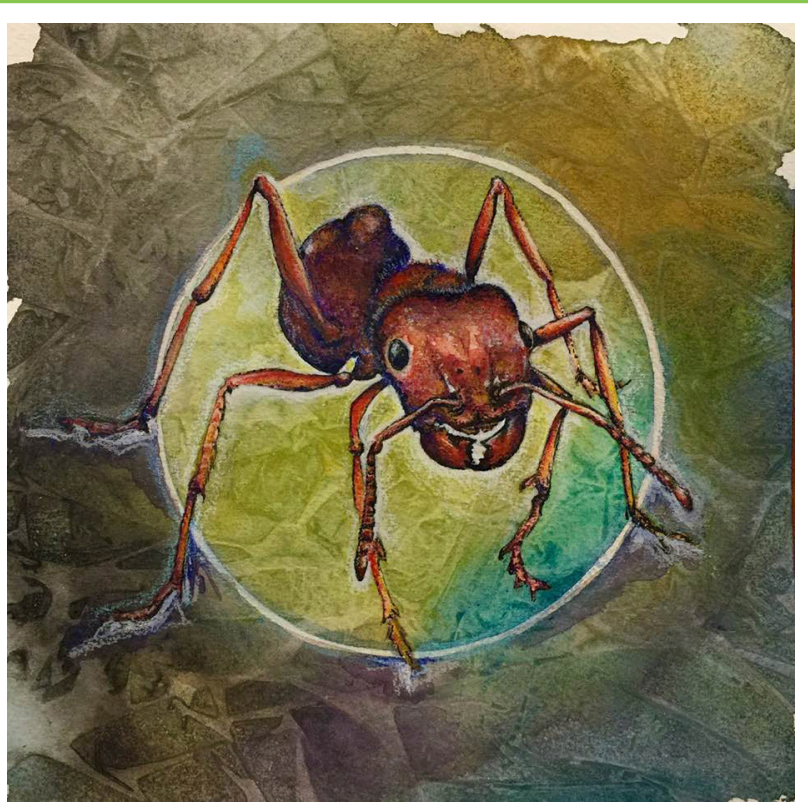

Figure 1

organisms, including plants, animals, and microorganisms in their environment. These interactions can take place between individuals of the same species-like your interactions with your friends and family-or with different species, like your interactions with animals and plants. But some organisms interact more than others. Ants are some of the most interactive organisms in the world, and a single ant can have thousands of interactions in a single day [1]. An ant may communicate with her sisters about the location of food, she may feed her colony's queen or care for the young growing ants in her colony, and she may even fight with neighboring ant colonies for territory (Figure 1). These are all examples of intraspecific interactions, meaning they involve individuals of the same species. But an ant will also interact with different kinds of organisms too-with plants, other insects, fungi, humans, even bacteria! Interactions that take place between individuals belonging to two or more species are called interspecific interactions.

Biologists are interested in how species interact with each other, because these interactions can influence the way that species live and change over time, and because these interactions can affect the ecosystems in which they occur [2]. There are many different species interactions in nature, so biologists classify them according to how many species are involved (for example, intraspecific or interspecific interactions), and whether the interaction has positive, negative, or neutral consequences for the interacting organisms. This article will use ants as examples to demonstrate the major types of species interactions that occur all around us, every day, everywhere in the world. 
Figure 2

A Megaponera ant has been on a successful hunt and has stuffed her mouth full of termites to feed to her nestmates.

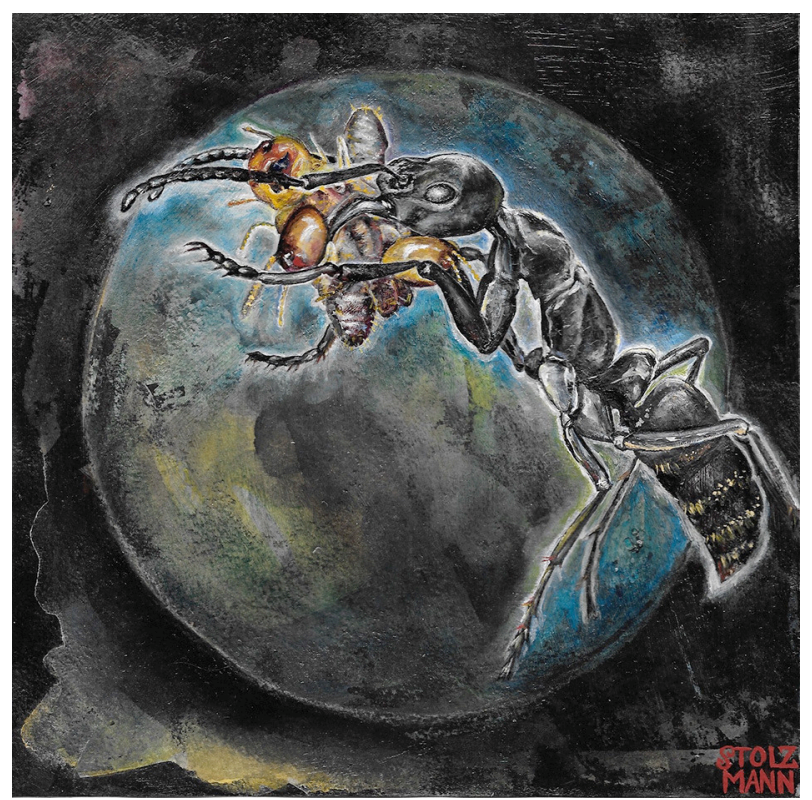

Figure 2

\section{NEGATIVE SPECIES INTERACTIONS}

Many interactions between species have winners and losers: one individual benefits, and the other one suffers. These are called negative species interactions. For example, predation is a type of species interaction in which one organism (a predator) eats another organism (the prey) -this is good for the predator but very bad for the prey! Different ant species can eat many different things, and some ants are important predators. Predatory ants often eat other insects like termites and caterpillars, while other ants eat only plants or fungus. Megaponera ants have only one food-termites-and these ants organize huge hunts in which worker ants infiltrate termite colonies, capture as many termites as they can carry, and bring the termites back to the ant nest to feed to their larvae [3] (Figure 2). But even though many ants are predators, they can also be prey for other animals. Lots of animals like to eat ants: birds, ant eaters, even humans in some parts of the world! An animal that eats ants is called a myrmecophagous animal. The authors of this paper have eaten ant larvae that were specially prepared, and we can confirm that they are both delicious and nutritious.

Another type of negative interaction is called parasitism. Just like predation, parasitism has winners and losers, but the losers typically survive the interaction. Parasitism occurs when an organism steals a resource from another organism. For example, some ant species called slave-making ants parasitize neighboring ant colonies by stealing their larvae. The slave-making ants raise the stolen young ants to work in their colony. Many other organisms parasitize ant colonies, including some very special butterflies! These butterflies trick ants into thinking that the butterfly caterpillar is an ant larva, so that ants will 
bring the caterpillar into the ant nest and feed the caterpillar as if it were an ant. Because the butterfly caterpillar benefits by taking food that would otherwise be given to the ants' young, this is an example of a parasitic interaction [4].

Competition is another type of negative species interaction. Competition occurs when two organisms fight for the same resource, such as food, territory, or mates. Ants are great competitors, and even though they are small they can compete with organisms much bigger than they are. Some ants in the savannahs of East Africa do not build underground nests, but instead live in Vachellia trees. These trees are a popular food source for large animals like elephants and giraffes, meaning that the ants must protect their homes from being eaten. Who do you think would win in a competition between an ant and an elephant? It is easy to think that an ant is no match for these large animals, but when an elephant starts feeding on a tree where ants have made their home, the ants will respond by ferociously attacking the elephant, even climbing inside the elephant's trunk to bite and sting it.

\section{POSITIVE SPECIES INTERACTIONS}

Unlike predation, parasitism, and competition, some species interactions do not have winners and losers, they have winners and winners. When both species benefit from an interaction this is considered a positive species interaction, often called a mutualism. One of the most amazing things about ants is that they have so many mutualisms with other organisms. Some of these mutualisms involve other insects, like aphids. Aphids are small, soft, and slow insects that feed on plant juices, and even though aphids might seem like they would be easy and tasty prey for ants, most ants do not prey on aphids. Instead, the ants guard and protect aphids from other predators, while feeding on the nutritious sugary liquid that aphids excrete. Because the ants get food and the aphids get protection, both species benefit from the interaction.

Ants also form mutualisms with plants, for example by protecting plants from herbivores (like elephants), cleaning parasitic fungi off of plants' leaves, or dispersing plant seeds. The seeds of bloodroot plants have special structures called elaiosomes that ants like to eat. When an ant finds a bloodroot seed it will take the seed back to the nest, remove the elaiosome from the seed, and feed the elaiosome to the ant larvae. The ant will then typically discard the seed underground, where it has a good chance of sprouting (Figure 3). By taking seeds back to the ant nest, the ants transport seeds far away from parent plants, so when new seedlings sprout, they do not compete with their parent plants for light or nutrients. This is beneficial for the plants as well as for the ants. 
Figure 3

Bloodroot plants make red seeds with special white structures called elaiosomes that attracts ants. When ants find the seeds, they take them back to their nests to feed the elaiosomes to their larvae, while also dispersing the seeds far away from the parent plants.

\section{Figure 4}

A large leafcutter ant carries a leaf fragment through the jungle, and a small worker rides on top to fight off enemies while the leaf is in transit.
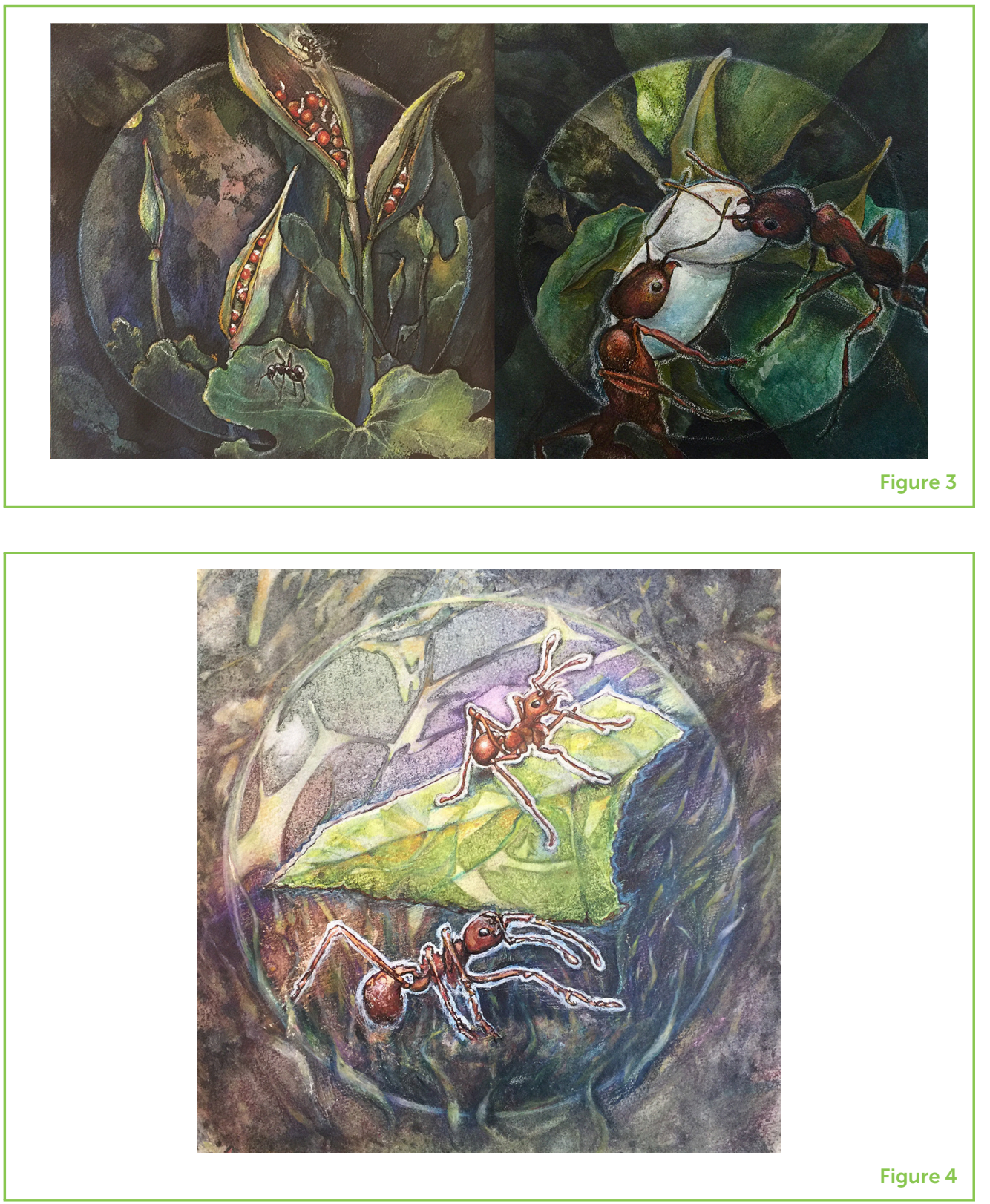

Many plants rely on ants to transport their seeds; in fact, seed dispersal by ants is so common it has its own name, myrmechochory.

Other ants engage in mutualisms with microorganisms like fungi and bacteria. Leafcutter ants live in jungles and are well-known for cutting up small pieces of leaves, which they carry back to their nests (Figure 4). But leafcutter ants do not actually eat leaves. Instead, they use the leaves to build underground compost piles on which they grow a special type of fungus, and they feed this fungus to their young. The ants benefit from this interaction because the fungus provides food for the colony, and the fungus benefits because the ants bring it fresh leaves to grow on, keep it free from pests, and carry the fungus along when they establish new colonies [5]. 


\section{CONCLUSION}

Species are interacting all around us, in all ecosystems in the world-from deserts to forests, rivers to oceans, and farms to cities. All organisms live within ecological communities and have important relationships with other organisms. You can see examples of positive and negative interactions in ants, humans, and many other species. How would you classify an interaction between a child and a pet? What about a gardener and a vegetable? Or a bee and a flower? How about a human and an ant? We hope you will notice and think about the interactions that occur around you every day, though they are easy to miss. The more we know about interactions between plants, animals, and microorganisms, the better we will be at understanding how individual species and entire ecological communities function and change.

\section{ACKNOWLEDGMENTS}

Piotr Naskrecki graciously granted permission to use his photograph as the basis for the original painting, Termite Raid (Figure 2). MW was supported by a National Science Foundation Postdoctoral Research Fellowship in Biology (1309425).

\section{REFERENCES}

1. Chomicki, G., and Renner, S. S. 2017. The interactions of ants with their biotic environment. Proc. R. Soc. B Biol. Sci. 284:20170013. doi: 10.1098/rspb. 2017.0013

2. Barraclough, T. G. 2015. How do species interactions affect evolutionary dynamics across whole communities? Annu. Rev. Ecol. Evol. Syst. 46:25-48. doi: 10.1146/annurev-ecolsys-112414-054030

3. Schmidt, C. A., and Shattuck, S. O. 2014. The higher classification of the ant subfamily Ponerinae (Hymenoptera: Formicidae), with a review of ponerine ecology and behavior. Zootaxa 3817:1-242. doi: 10.11646/zootaxa.3817.1.1

4. Als, T. D., Vila, R., Kandul, N. P., Nash, D. R., Yen, S. H., Hsu, Y. F., et al. 2004. The evolution of alternative parasitic life histories in large blue butterflies. Nature 432:386-90. doi: 10.1038/nature03020

5. Hölldobler, B., and Wilson, E. O. 2011. The Leafcutter Ants: Civilization by Instinct. New York, NY: Norton.

SUBMITTED: 11 October 2018; ACCEPTED: 19 March 2019; PUBLISHED ONLINE: 09 April 2019.

EDITED BY: Martha Helena Ramírez-Bahena, Instituto de Recursos Naturales y Agrobiología de Salamanca (IRNASA), Spain

CITATION: Whitaker MRL and Stolzmann BJ (2019) Species Interactions and Ants. Front. Young Minds 7:53. doi: 10.3389/frym.2019.00053 
CONFLICT OF INTEREST STATEMENT: The authors declare that the research was conducted in the absence of any commercial or financial relationships that could be construed as a potential conflict of interest.

COPYRIGHT () 2019 Whitaker and Stolzmann. This is an open-access article distributed under the terms of the Creative Commons Attribution License (CC BY). The use, distribution or reproduction in other forums is permitted, provided the original author(s) and the copyright owner(s) are credited and that the original publication in this journal is cited, in accordance with accepted academic practice. No use, distribution or reproduction is permitted which does not comply with these terms.

\section{YOUNG REVIEWERS}

\section{ADAM, AGE: 12}

Hi, my name is Adam. I live with my parents, older brother, dog, fish, and two birds. I am a big fan of Science and History. I like to draw, write, and read. My favorite sport is soccer (or football). I enjoy swimming in the ocean and playing video games.

\section{ALFONSO, AGE: 10}

I attend the Maristas Champagnat School.

\section{JAVIER, AGE: 12}

I am Javier, a 12 year-old boy and I love sports. I have been playing basketball and badminton for many years. I like very much playing the piano and writing and reading braille. But what I like the most is science. I love learning about space and in the future, I would like to study it because there are a lot of things which have not been discovered yet.

MIGUEL, AGE: 10

I am Miguel.

\section{NICOLÁS, AGE: 11}

Hello! I am a lover of science, technology, sports. I would like to help you to improve these amazing articles because I think that they are so interesting for Young Minds. It is so exciting to be a global reviewer so thank you for all and bye. 


\section{AUTHORS}

\section{MELISSA R. L. WHITAKER}

Dr. Melissa Whitaker is a bug-lover and a foodie, sometimes at the same time. Her research focuses on the evolution of cooperation and diet among lycaenid butterflies, a group that engages in fascinating interactions with ants. She has conducted research in over 15 countries and thinks being a professional biologist is the coolest job ever. *melliwhitaker@gmail.com

\section{BONNIE J. STOLZMANN}

Bonnie Johnson Stolzmann is a Denver-based fine artist and illustrator. She strives to ignite the imagination of her viewers while also truthfully capturing her subjects. She dreams of writing and illustrating children's books with her two young daughters. Her scientific illustrations have been published in association with The Max Planck Institute for Chemical Ecology, The University of California, and Harvard University. She is represented by Spark Gallery in Denver Colorado. 